\title{
Impact of Facebook on Academics of College Students
}

DOI : 10.36909/jer.ICETET.14999

\author{
Ms. Deepali Mahajan, Dr. C. NamrataMahender. \\ Department of CS and IT, Dr. B. A. M. University, Aurangabad, Maharashtra,India. \\ *Email: deepaliborole@gmail.com;nam.mah@gmail.com
}

\begin{abstract}
Facebook has become the most popular among the students. Hence there is a need to examine the effects of excess use of Facebook. There are different factors discovered which leaves greater impact on the students, this study examines the effects of using Facebook on undergraduate and postgraduate students and finding the association between the excess use of Facebook and academic of the students. A cross-sectional design was used to collect the data from college and university students who are using the Facebook. Total 106 participants have participated in an offline survey. The research has shown that there is a positive correlation between Excess use and Academics of students. The results suggests that the moderate use of Facebook can help students in their studies.
\end{abstract}

Key words: Addiction, Facebook, Social media, Academics.

\section{INTRODUCTION}

Now a days Social networking sites have gained renown over the past decade. This world welcomes the new technologies and make use of it for the betterment of current technologies, communication and Education. It becomes the part of life. Regularly people use themIt assists people in becoming more informed, enlightened, and up to date on international events. Humanity is exposed to a better method of doing things as a result of technological advancements[1]. Social networking sites such as Facebook, WhatsApp, Skype, Google Talk, Google Messenger, Twitter, Snap chat are 
popular in the students. Adolescents and adults spend a significant amount of time on the internet for varies purposes. Some researchers stated that the use of the internet can be helpful for students to complete academic work more effectively and efficiently and can be supportive for communication enhancement, social connection, and even developing technical skills. with this heavy usage of web, a large part of this generation's social and emotional development is occurring while on the internet and on cell phones[2] New technology can change society, but a fear about the negative has arose about its physical, social and psychological consequences[4] There is need to understandthe global changes affecting the adolescent and adult behaviour and their academic performance[5].

Students are interested in living and enjoying virtual world. They don't have the real friends. Virtual friends are more in number, and this online relationship is developed through social networking sites. Due to rapid flourishing of social networking sites the use of traditional communication channels have been declined. As a result, social networking sites are now the primary medium for sharing, disseminating, commenting on, and tagging information. [6] One of the most popularly used social networking site is the Facebook. Irrespective of age and gender Facebook leaves the impact on all people.

\section{WHAT IS SOCIAL MEDIA?}

Social networking sites are nothing but the web applications which allow users to share their views and have communication with other people those are also using this kind of applications. It is a media for exchanging the information among the people in the form of personal opinion and information. People interact through social media by creating, sharing, exchanging, and commenting on each other's creations in various networks. This kind of applications can be used as a tool for mass communication. Social media, according to Kietzmannn, is a type of technology that uses mobile and web-based technology to provide highly interactive platforms for individuals and communities to share, co-create, discuss, and 
modify user-generated content. It's a website that not only provides you with information, but also interacts with you while doing so. Once content is shared on a social media platform, it becomes a discussion because all users who have accounts on that platform can interact with all posts [7].

There are many social media websites available on the internet like Facebook, WhatsApp, Snap chat, Twitter and many more. Social media now become very popular for exchanging the thoughts and information.

\section{FАCEBOOK}

Facebook is a social media which allows the user who have sign up to connect with peoples like friends, colleagues online. User can share the pictures, videos, music and also their own creations and opinion with the friends list. With over two billion users globally, Facebook is the most popular online social network. For many people, social media has become a vital part of their daily lives during the last decade. Facebook was created to provide a networking medium for people mainly students to interact with others.

\section{WHATSAPP}

Identify applicable funding agency here. If none, delete this text box. WhatsAppis mainly used on smartphones. It is a messenger tool which is freely available for download. Using this application user can share text messages, images, audio and video also. It needs the internet for sharing this kind of in-formation. The use of WhatsAppis similar to that of the text messaging services. The cost of using WhatsAppis significantly less than texting messages as it is using inter-net for sending the messages. Not only the text or multimedia messages and images but also documents and locations can be share by using this application. More than one billion people worldwide use it to stay in touch.

\section{SNAP CHAT}

Snap Chat is another popular messaging software that allows users to send and receive photos and videos (called snaps). Shared data in this application is automatically deleted 
after viewing. It is particularly popular among children and teenagers because it includes functions such as adding filters, lenses, and other effects to photos and videos, as well as sharing them with friends.

\section{TWITTER}

Twitter is a system for'microblogging.' Users can send and receive tweets with it. Tweets are short posts that are circulated on Twitter. Users with comparable academic and personal interests can be followed. If a person follows someone on Twitter, he can see their tweets in his 'timeline.'

\section{SKYPE}

Skype is a piece of software. It allows people all around the world to communicate. Skype video and voice one-to-one and group calls, as well as sending instant messages and sharing files with other Skype users, can be used for interpersonal and business communication.

\section{GOOGLE MEET}

Google meet is a Google App that is use to communicate with your Google Contacts. Google meet is a desktop pro-gram, it allows users to send instant message to their contacts, and also it is used for call them and voice chat with them as well.

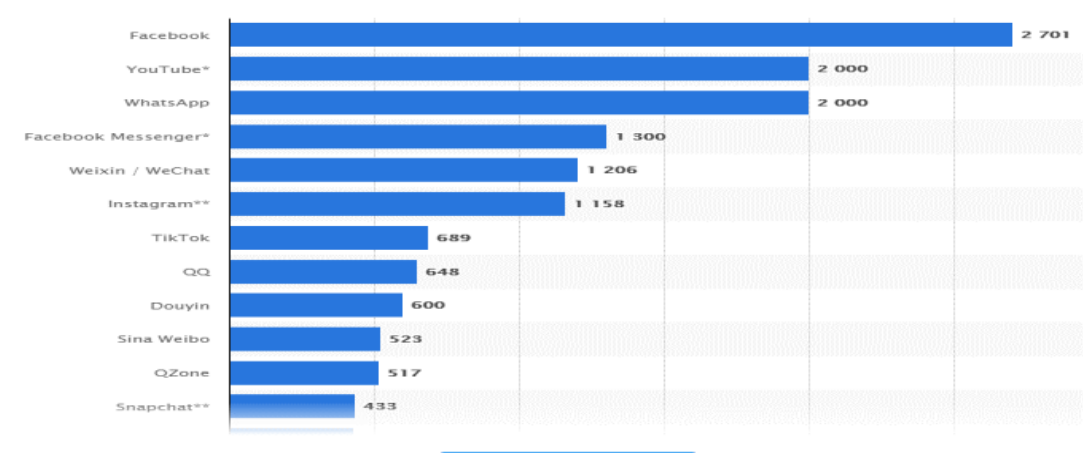

Figure 1Most popular social networks worldwide as of October 2020, ranked by number of active users (in millions)

Among all of these social media programmes, Facebook has grown in popularity and now has the most users on the planet. There are more than 4.14 billion active users of social networking sites around the world, with Facebook being the most popular with 2701 million 
users. With over 310 billion Facebook users, India currently boasts the largest number of users in the world. [8]. According to statistics, roughly 94 percent of undergraduate students are avid Facebook users who spend countless hours on a daily basis. The main concern about using Facebook is its impact on student's academics and health. According to a study it was reported that students that has excess time on Facebook negatively results in academic performance and health issues [9]. Due to its social and informational benefits, Facebook has become an indispensable part of students' daily lives. Students and teachers communicate via social media platforms such as Facebook and WhatsApp. Students use Facebook to pass the time, form social bonds, and entertain themselves in addition to academic communication. It was shown that Facebook has become a prominent platform for gathering and disseminating information.

The purpose of this study is to find the relationship between internet addiction factors Excess use and Academics of the students.

\section{LITERATURE REVIEW}

According to M. Owusu-Acheaw and Agatha Gifty Larson, social networking among students has grown in popularity. It is a set of websites, services, and behaviours that encourage collaboration, community building, involvement, and sharing on the internet." It's a method to connect with pals outside of school as well as on campus. Because of the popularity of social media sites, economists and academicians are asking whether students' grades are affected by how much time they spend on these sites.

Drury (2008) defines social media as "online resources that people use to share con-tent like video, photos, images, text, ideas, humor, view, gossip, news”. Safko and Brake (2008)

defined social media as "activities, practices, and behaviors among communities of people who get together online to share information, knowledge, and opinions using conversational media. The activist media are Web-based applications that make possible to create and easily transmit content in the form of text, images, videos, and audios". The use of social networking sites in academics is common, and such sites provide tools and new modes of 
communication to solve new difficulties, according to the European Higher Education Area (EHEA).For example, such as association, the free flow of information and the generation of content for the construction of knowledge have recently been applied to education [10].Raymond OwusuBoateng\&AfuaAmankwaa gives qualitative approach inassessing impacts of using social sites. Over the course of two weeks, ten (10) participants were randomly selected and interviewed. After studying the phenomena that were of interest to the study and transcribing the various responses of the participants, the findings reveal that social media is widely used by students of higher education, and that participants agree that social media plays a significant role in the development of their academic lives. To investigate how people use the internet, Kuan-Yu Lin and His-Peng Lu (2011) used network externalities and motivation theory.

College students use social networking sites. Lin and Lu (2011) discovered that "Enjoyment" was the most influencing factor for the increased use of Social Networking Sites among college students after performing an empirical study with 402 samples using the Structural Equation Modelling (SEM) Approach. AJAYI, Samuel Oyedokun (Ph.D.) and AKOLE, OlatubosunBusuyi investigate the effects of social networking on NCE College of Education students. The study was guided by four research questions. The questionnaire was used as the data collection tool in the survey procedure. The study found that 263 (98.9\%) of students use social networking to keep in touch with friends and family. The study also found that 196 (73.7\%) of respondents said that social networking interferes with their reading habits. Conclusions and recommendations were given based on the findings.

\section{PROPOSED METHOD \\ DATA COLLECTION}

This study employed a cross-sectional design for the collection of data. Use of questionnaires is the best way to reach to large number of people in the form of survey. The 
questions in questionnaires help us to analyze the effects of Facebook on the student's health, student's psychology and student's academic performance. We developed an original questionnaires which includes 31 items with the multiple options. While designing the questionnaires we have consider the different factors affecting on the user like Silence, Excess use, Neglect of Work, Anticipation, Self-Control, Neglect of Social Life, and Education. The participant can easily answer these questions. Survey questionnaires was prepared and distributed to undergraduate and postgraduate students for their responses. Total participants were 106 which includes UG, PG college and university students of Marathwada region Maharashtra.

This questionnaires can help to reflect the effect of Facebook on different aspects of student's development. Questions has been drawn in English language instead of using any regional language, to avoid language barrier for students belongs from different cultures, religions or regions. Hardcopy of the questionnaires was distributed among students and collected after they marked their responses. In this some students dint respond for some questions. We have ignore such students as they have submitted blank responses.

\section{ANALYSIS OF DATA}

For analyzing the collected data SPSS software is used. Calculated frequencies, percent. In this study we are focusingon the factors like Excess use and Academics. We have consider the set of questions which shows the impact of these factors only. We are finding the correlation between these factors and the effect of excess use on the academics of the students.

We have designed multiple question which will analyze the effect of same factor. So a compound variable has been generated for cumulative effect of all the questions for same factor and then these compound variables have been used for the analysis. In this study we are discussing only two compound variables that is Excess use and Academics. For excess use we use the questions having options in ordinal measure and for academics the questions 
having their responses in yes/no form that is nominal measure.

Table below shows the questions drawn for extracting the information about Excess use and effect on academics.

Table 1 Questionnaires included in this study

\begin{tabular}{|c|c|c|}
\hline Sr. No. & Questions & \\
\hline 1 & How long are you using Facebook? & \multirow{5}{*}{$\begin{array}{l}\text { Used for } \\
\text { measure } \\
\text { Excess } \\
\text { Use }\end{array}$} \\
\hline 2 & How much time you spend in a day on Facebook? & \\
\hline 3 & What is the frequency you post status updates on Facebook? & \\
\hline 4 & $\begin{array}{l}\text { Do you check Facebook as the first thing after getting up in } \\
\text { the morning? }\end{array}$ & \\
\hline 5 & Last thing before going to bed do you check the Facebook? & \\
\hline 6 & Have you created any academic study related group? & \multirow{3}{*}{$\begin{array}{l}\text { Used for } \\
\text { measure } \\
\text { effects on } \\
\text { Academi } \\
\text { cs. }\end{array}$} \\
\hline 7 & $\begin{array}{l}\text { Have you improved your communication skill using } \\
\text { Facebook? }\end{array}$ & \\
\hline 8 & Do you use Facebook for solving academic assignments? & \\
\hline
\end{tabular}

\section{RESULTS}

\section{Result for Excess Use}

The questions 1 to 5 given in the above table asked about the Facebook use and measures the impact in the form of Excess use. According to the response of respondent we can identify the Facebook addiction.

Table 2 shows frequency and percentage for question number 1 for the different options. The highest percentage shown for the time period of 1 to 5 years is $40.7 \%$ (37)

In Table 3 results shows that $72.8 \%$ (75) students spends 2 hours in a day only on Facebook. Like this tables, we have computed the frequency and percentage for all 8 questions given in Table 1 for the analysis of Excess use and impact on academics.

Table 2.Frequency and percentage of Question How long are you using Facebook?

\begin{tabular}{|l|l|l|l|l|l|}
\hline & Frequency & Percent & Valid Percent & $\begin{array}{l}\text { Cumulative } \\
\text { Percent }\end{array}$ \\
\hline
\end{tabular}




\begin{tabular}{|l|l|r|r|r|r|}
\hline & Less than 1 year & 30 & 28.3 & 33.0 & 33.0 \\
\cline { 2 - 6 } & 1 to 5 years & 37 & 34.9 & 40.7 & 73.6 \\
\cline { 2 - 6 } & 5 to 10 years & 23 & 21.7 & 25.3 & 98.9 \\
\cline { 2 - 6 } & more than 10 years & 1 & .9 & 1.1 & 100.0 \\
\cline { 2 - 6 } & Total & 91 & 85.8 & 100.0 & \\
\hline Missing & System & 12 & 11.7 & & \\
\hline Total & & 103 & 100 & & \\
\hline
\end{tabular}

Table 3. Frequency and percentage of Question How much time you spend in a day on Facebook??

\begin{tabular}{|l|l|r|r|r|r|}
\hline & & Frequency & Percent & Valid Percent & Cumulative Percent \\
\hline \multirow{7}{*}{ Valid } & 2 hours & 75 & 72.8 & 93.8 & 93.8 \\
\cline { 2 - 6 } & 4 hours & 2 & 1.9 & 2.5 & 96.3 \\
\cline { 2 - 6 } & 4-6hours & 1 & 1.0 & 1.3 & 97.5 \\
\cline { 2 - 6 } & More than 6 hours & 2 & 1.9 & 2.5 & 100.0 \\
\cline { 2 - 6 } & Total & 80 & 77.7 & 100.0 & \\
\hline Missing & System & 23 & 22.3 & & \\
\hline Total & & 103 & 100.0 & & \\
\hline
\end{tabular}

It shows that $62.1 \%$ (54) students are rarely post status updates on Facebook and $8 \%$ (7) students more frequently post status updates. For question 4, 55.1\% (49) students never check

the Facebook as the first thing after getting up in the morning and $32.6 \%$ (29) students sometimes checks the Facebook as the first thing in the morning. Question 5 shows the result as $36.4 \%$ (32) students check the Facebook before going to bed.

\section{RESULT FOR EDUCATION}

The questions 6,7 and 8 showing the results regarding the effect of using Facebook on academics or education. For Q.6 it shows that $73 \%$ (65) students are not create any study 
related group. Whereas $27 \%$ (24) students prefer to create the groups related to study. Q.7 is about to improvement in communication skill. $81 \%$ (73) students are agree and $18.9 \%$ (17) are not agree on having improvement in their communication skill. Result of Q8 shows that $80.9 \%$ (89) students not using and $19.1 \%$ (17) students are using the Facebook for solving their assignments.

Table 4. Pearson Correlation among Excess use and Education/Academics.

\begin{tabular}{|l|l|r|r|}
\hline \multicolumn{2}{|c|}{} & Excess Use & Education \\
\hline \multirow{5}{*}{ Excess Use } & Pearson Correlation & 1 & .014 \\
\cline { 2 - 4 } & Sig. (2-tailed) & & .904 \\
\cline { 2 - 4 } & N & 77 & 74 \\
\hline \multirow{2}{*}{ Education } & Pearson Correlation & .014 & 1 \\
\cline { 2 - 4 } & Sig. (2-tailed) & .904 & \\
\cline { 2 - 4 } & N & 74 & 86 \\
\cline { 2 - 4 } & & & \\
\end{tabular}

Results from Table 4 indicates positive correlation among Excess use and Education. $\mathrm{r}(86)$ $=.014, \mathrm{p}<0.001$. So increase in use is associated with increase in academics. We have started our work presuming excess use of Facebook will be having negative impact on academics of students, but after the survey analysis it has been found that there is positive correlation among Excess use and Education. After analysis we have also observed that this positive correlation may also be due to responses regarding usage was averagely found to be moderate.

\section{CONCLUSION}

The results of this study, which included 106 UG and PG students, is a moderate positive association between Excess use and Education. When computing the compound variable of Excess use we find that it is a moderate use of Facebook among the students. 98.3\% students use the Facebook for 2 hours a day which can be consider as the moderate use of FB. In case of Education we observed that $75 \%$ students are not interested in creating academics related 
groups and $80.9 \%$ students are not using Facebook to solve the assignments but $81 \%$ students are improved their communication skill. So here also moderate effect of using Facebook on academics can be observed.

\section{REFERENCES}

PeterOsharive, 2016. Social Media and Academic Performance of The Students in Universities in Lagos State. Journal 2(5), 99-110.

Owusu-Acheaw M., Agatha GiftyLarson2015.Use of Social Media and its Impact on Academic Performance of Tertiary Institution Students: A Study of Students of Koforidua Polytechnic, Ghana.Journal of Education and Practice, Vol.6, No.6.

Gwenn Schurgin O'Keeffe, Kathleen Clarke-Pearson,2011. Council on Communications and Media, The Impact of Social Media on Children, Adolescents, and Families, From the American Academy of Pediatrics Clinical Report Vol. 127, Issue 4.

Niall McCrae,SherylGettings and Edward Purssell, 2017. "Social Media and Depressive Symptoms in Childhood and Adolescence: A Systematic Review", Adolescent Res Rev $2: 315-330$.

Osharive Peter, 2015. "Impact of Social Networking Sites on academic performance of students (Research Project of B.A(Ed)), Faculty of Education, University of Lagos.

María Teresa OrtegoAntón, Elena Jiménez García and PurificaciónFernándezNistal, 2015.Linguistic behaviour in social networkingsites used as academic and educative communication tool, Procedia - Social and Behavioral Sciences 212,123 - 130

\section{Evans Atteh, Isaac Assan-Donkoh, Yaw Ackaah Mensah, Augustine Boadi, Silas} CudjoeBadzi and Vincentia TerkworLawer, 2020. A Thoughtful Overview of Social Media Usage among Students and Its Impact on their Academic Work, Asian Journal of Advanced Research and Reports 8(3): 30-39, Article no.AJARR.52990 ISSN: 2582-3248. Statista,https://www.statista.com/statistics/272014/global-social-networks-ranked-by- 
number-of-users, last accessed 2021/01/20

NidaTabassum Khan, Sohail Ahmed, 2018. Impact of Facebook Addiction on Students Academic Performance, Research in Medical \& Engineering Sciences5 (2). RMES.000607. Ali Waqas Muhammad Afzal, FakharZaman and Muhammad Sabir, 2016. The Impact Of Social Networking Sites' Usage On The Academic Performance Of University Students Of Lahore, Pakistan,Waqas et al. Int. J. Soc. Sc. Manage. Vol. 3, Issue-4: 267-276. 